\title{
NEGOCIACIÓN, MEDIACIÓN Y CONCILIACIÓN, COMO MÉTODOS ALTERNATIVOS DE RESOLUCIÓN DE CONTROVERSIAS
}

\begin{abstract}
Núñez Ojeda, RaúlĘdiciones Jurídicas de Santiago, enero de 2009, Santiago de Chile, 220 pp.

Núñez Ojeda es profesor de Derecho Procesal de la Universidad de Chile, Doctor en Derecho, integrante del Foro para la Reforma Procesal Civil del Ministerio de Justicia y de la comisión de estudio sobre sistemas preferentes de solución de con囚ictos de esta reforma. Su libro expone la investigación desarrollada durante 2005 y 2006 sobre mecanismos no adversariales en los sistemas procesales civiles español, anglosajón, alemán, italiano y francés, a los cuales dedica extensos capítulos, revistiendo particular interés su análisis de la mediación.
\end{abstract}

Al revisar el sistema procesal español, el autor destaca la aplicación de este método en las comunidades autónomas, como Cataluña y el País Vasco. También, la in囚uencia que han ejercido a favor de esta instituciones de la Unión Europea, como la Recomendación (98) I de la Comisión de Ministros de los Estados miembros sobre la Mediación Familiar. Los fundamentos que arguye son el aumento de litigios familiares y el coste social y económico elevado para los Estados; la necesidad de proteger los intereses del niño y su bienestar, con los problemas que entraña la guarda y el derecho de visitas en supuestos de separación o divorcio; en el desarrollo de vías para reglamentar una solución amistosa de los litigios y en el reconocimiento de la necesidad de reducir los con flictos en interés de todos los miembros, así como en las características de este tipo de litigios. En cuanto a los principios rectores de este mecanismo, enfatiza su necesaria independencia frente a los procesos judiciales.

Respecto al sistema anglosajón, el autor explica que la explosión de los ADR (Alternative Dispute Resolution) se ha debido a tres motivos: el colapso de los órganos jurisdiccionales, por el exceso de causas, el costo y demora que conllevan; el sentimiento de la comunidad de ausencia de mecanismos privados para resolver las controversias; y la incapacidad intrínseca del sistema procesal de garantizar el acceso a la justicia de todos. La mediación se recomienda especialmente cuando entre las partes existe una relación que ha de perdurar en el tiempo, cuando existen delicadas posiciones de reputación, confidencialidad u otras, cuando existen cuestiones técnicas complejas o se requiere premura para resolver la controversia. Existen distintos instrumentos que la contemplan y de ffinen, como el código estadounidense, los estatutos de Florida y la Uniform Mediation Act.

Respecto al sistema civil alemán, el autor señala que si bien Alemania no tiene una cultura de negociación tan marcada como Estados Unidos o Inglaterra, la mediación es una vía recurrente para llegar a acuerdos y que las empresas alemanas han 
incrementado su uso para abordar sus conflictos citando como ejemplo a Siemens y Ericsson que han acudido a la Asociación para la Mediación Comercial y Manejo de Conflictos. Indica que existe una mediación intraprocesal que Ilevan a cabo los jueces, cuyo límite con la conciliación se hace difuso; y una mediación prejudicial obligatoria para asuntos de baja cuantía (que no excedan de 750 euros). Asimismo, se usan los acuerdos y cláusulas de mediación que se incorporan a los contratos donde las partes acuerdan el procedimiento y ámbito de aplicación de esta instancia. Aclara que si bien el Código Procesal Civil alemán no se refiere específicamente a ella, se le aplican por extensión las reglas del arbitraje. Las materias en que se usa con más frecuencia son separación y divorcio, conflictos medioambientales, de derecho económico, laborales, vecinales, de arrendamiento, de los consumidores y delincuencia juvenil.

Respecto al sistema italiano, Núñez Ojeda indica que la crisis del enjuiciamiento civil ha generado un ambiente propicio para el desarrollo de los mecanismos alternativos al juicio. Leyes de la década del sesenta han regulado la mediación y los artículos 1754 a 1765 y 2950 del Código Civil se refieren a ella. Señala también que en Italia la mediación se equipara a la conciliación.

En cuanto al sistema procesal civil francés, el autor indica que ya un decreto de 1955 instituyó un procedimiento de mediación social, en virtud del cual se requería la intervención del ministro del Trabajo en casos de conflictos laborales sobre remuneraciones, el que fue generalizado por una ley de 1957 y por las Leyes de Auroux en 1982. El Código del Trabajo actual dedica una sección a la mediación y otra al arbitraje y a la conciliación. En materia civil, la mediación fue introducida por una ley de 1995, pero antes la Corte de Casación la había incluido como mecanismo de resolución de conflictos en 1993. Actualmente, en materias civiles se identifica la mediación convencional y la judicial. En esta última, el juez conociendo de un litigio puede proponer a las partes resolver sus diferencias ante un mediador. Así lo contempla el nuevo Código de Procedimiento Civil.

Por último, consideramos especialmente atractivo el capítulo que el autor dedica a exponer sus conclusiones, estadísticas y propuesta normativa. Así, por ejemplo, plantea una serie de cuestiones que pueden suscitarse a partir de la mediación como si la prejudicial ha de ser obligatoria o facultativa, si interrumpe o suspende la prescripción en relación a la demanda judicial posterior, si es el juez quien debe designar al mediador, o las partes, los principios que han de regirla, el deber de confidencialidad del mediador, su rol en materia probatoria, su remuneración y responsabilidad. Desde su perspectiva, la mediación debe ser ágil y desformalizada, pero respetando la garantía constitucional del debido proceso.

Este eminente procesalista se sorprende de que, en breve tiempo, los sistemas procesales civiles de Europa continental hayan comenzado a mirar hacia los sistemas 
procesales anglosajones en la búsqueda de soluciones pragmáticas, eficaces y rápidas para la crisis de la justicia civil, tendencia a la que nuestro país no está ajeno.

Excelente trabajo cuyo mayor aporte, en nuestra opinión, lo constituye esta visión globalizada del apogeo de los mecanismos alternativos al juicio para resolver las controversias, justo cuando se debate su inclusión en la reforma procesal civil de nuestro país, y todavía existe cierto desconocimiento y reticencia acerca de su validez.

Adriana Palavecino 